\title{
Financial Literacy and Individual Financial Behavior: Evidence from Lebanon
}

\section{Roger Loutfi ${ }^{1^{*}}$ and Bachir EI Murr ${ }^{2}$}

${ }^{1}$ Ministry of Finance, Lebanese University, Beirut, Lebanon

${ }^{2}$ Faculty of Economics and Business, Lebanese University, Beirut, Lebanon

"Corresponding author: Roger Loutfi, Museum Street, Sami El Solh, Lebanon, POB: 116-5133, Tel: +96176945373; E-mail: roger_loutfi@hotmail.com

Received date: Aug 01, 2018; Accepted date: Aug 13, 2018; Published date: Aug 20, 2018

Copyright: (c) 2018 Loutfi $\mathrm{R}$ et al. This is an open-access article distributed under the terms of the Creative Commons Attribution License, which permits unrestricted use, distribution, and reproduction in any medium, provided the original author and source are credited.

\begin{abstract}
In the alignment of the research works aiming to associate the financial literacy status to a specific framework and environment, the present paper objects to define the financial literacy character and behavior of individuals living in a small open economy, like Lebanon, where a developed banking sector exists. For this concern, a statistical study is performed looking forward to identify the individual financial literacy character of individuals with regards to personal and socioeconomic features forging their personality. A particular attention is accorded to the financial background, awareness and advice, the financial literacy path through, and the connection of the career success with financial education, individual financial behavior and familiarity with financial institutions and products.
\end{abstract}

Keywords: Financial literacy; Financial behavior; Career success

\section{Introduction}

The increased variety of financial products in the twenty first century caused increased complexity of financial decisions and increased challenges for economic and financial activities. An individual's ability to manage his personal finance has become a tricky issue with the increased diversity of the economic issues, specificity of the financial markets and regulations, and abundance of the financial products. Consequently, researches have registered a strong move to study and evaluate the financial literacy among household members.

In this context, the aim of this paper is to describe the financial literacy framework in which Lebanese people behave. A trial has been made to assess the financial literacy context and the financial behavior as factors of the individuals' financial decision-making process. The impact that has the financial literacy status on the individuals' behavior and career success is accordingly addressed, in trying to appraise the status of the Lebanese people financial education. Do individuals belonging to different households, with different age, gender, education level and socio-economic background have the same financial literacy level and then the same financial behavior? To what extent the individuals' financial behavior and choices are affected by the financial literacy framework?

For that purpose, the study supports the following hypotheses:

H1: the financial literacy level is not acquired through the traditional education system.

$\mathrm{H} 2$ : the higher the socio-economic status, the higher is the financial literacy level.

H3: practice forms a main way impacting individuals' familiarity with financial issues and financial institutions.

H4: The habitude to plan and control expenditures is a matter of financial literacy level.
In these regards, the main objective of this paper is to assess the ability, awareness, and the attitude of individuals regarding the financial matters in a small open economy like Lebanon characterized by a relatively developed banking sector. It has a target to respond on general and specific issues related to the level of financial knowledge, the facility in which the Lebanese people perform their financial activities, and consequently their behavior when dealing with financial affairs. In addition, the study seeks to shed light on the consequences of financial illiteracy of individuals on their personal life and business success. We expect that results generated by the study will alarm both public and private sectors, and motivate them to take measures and implement policies aiming to improve the individual financial abilities. An effort is particularly made to render the results useful for the concerned stakeholders, such as the Ministry of Finance, the Ministry of Education, the financial institutions, and the education institutions in developing strategies and plans for awareness programs. Hope the results will constitute a platform seeking to develop priorities, tools and policies enhancing the financial skills of the Lebanese people.

\section{Review of Literature}

The financial literacy concept registered an evolution with time and place, rendering difficult to find a common definition. While some authors considered it as a broad concept, surrounding an understanding of economics and how household decisions are affected by economic conditions and circumstances, others apprehend it as focusing narrowly on money management, including budgeting, saving, investing and insuring, that involve two fields, the fundamental mathematical and language literacy or considered it as the ability to make informed judgments and to take effective decisions regarding the use and management of money [1-5].

While Remund [4] noticed that since 2000 the literature on financial literacy has focused on five domains, notably the knowledge of financial concepts, ability to communicate about financial concepts, aptitude in managing personal finances, skill in making appropriate financial decisions, and confidence in planning effectively for future 
financial needs, McKAY [6] mentioned that no one indicator or domain may be used alone to have an idea about the global financial capacity of a person. The different domains are so distinct conceptually and the sources of the used database are so different. It's only by examining the global results that one may address the financial character of a person and evaluate his financial capacity. For Bay et al. [7] there are three traditions concerned with financial literacy. The first tradition seeks to measure the level of financial literacy in different demographic areas; the second tradition investigates the effect of financial literacy on financial decisions. The third tradition studies the effects of financial education.

Still the definition of the financial literacy stipulated by the OECD (2011) as "... a combination of awareness, knowledge, skill, attitude and behavior necessary to make sound financial decisions and ultimately achieve individual financial wellbeing" the widely used one for it covers a large range of related issues.

The methodology used by researchers in this domain is also diversified [3]. The variety of the used tools goes with the multiplicity of concepts and approaches. The major part of studies undertake descriptive analysis to illustrate the state of financial knowledge, the behavior of the people when dealing with financial issues related to their life concerns, their job, and their professions, and the impact of the stakeholders strategies and policies. Many researches proceed to the diagnosis of the financial literacy in one country, lesser are those carrying out international comparative studies.

Some of these studies tackle this area of research marking differences between low and high income countries [8], others between age groups and gender or among SME managers [9-11].

Some studies shed light on the benefits of the financial literacy for life wellbeing, for work distress, social inclusion, marital satisfaction $[1,5,12]$, others undertake the question of the awareness to financial issues and the role of the educational system in the financial awareness and education [5], underlying that the financial capability may be build up at home [9], school [13,14], OECD's Program for International Student Assessment PISA [15], university [13-17], or when forging experience in doing life, performing job or managing business, or complemented by financial advice [18].

In these regards, financial literacy could serve to apprehend general economic and financial concepts [14], to perform job and make daily decisions, advanced financial decision like retirement plans and portfolio choices $[1,19,20]$ or to deal with banks and banking products and operations [2]. That's why the different stakeholders should be aware and put the necessary policies and programs to enhance the financial performance of individuals.

On the other side, while some studies tried to apprehend the socio economic impact on financial literacy, expressed through the parental effect, the professional status and domain and the income or wealth level $[21,22]$, many studies worked to define other factors supporting the financial literacy background, considering it like other forms of human capital [23], allowing to make complex financial decisions [14], to reach a rich array of investment opportunities [24], or at least as an assistance way to avoid welfare costs of financial mistakes [24], or financial stress [25].

\section{Methodology}

In order to tackle these issues for the Lebanese people, a statistical study is performed. For this purpose, a survey is administered to collect information regarding the financial literacy profile and the corresponding financial behavior of individuals, belonging to different Lebanese households. An innovative, easy to fill and compact form of questionnaire is developed, based on closed responses, allowing to assemble in the same manuscript information on the household level and on the individuals belonging to the household. This allows to apprehend the financial character of individuals living in the same context and to know to what extent children' financial personality and behavior are influenced by the parents profile and by the socio economic environment in which they grow up. A scale of five stairs (very good, good, satisfactory, poor, failing) is used to allow interviewees express their opinion when an assessment is requested. The novel form of questionnaire allows accordingly assessing the financial knowledge and behavior of individuals belonging to different households, social classes, professions, levels and fields of education and according to their gender, ages, and native regions. In this manner, it is possible to build up historical data at the household level and accumulate intergenerational information among household members that may be used for more than concern.

The survey is conducted on a random sample of 500 households regrouping 1933 individuals. The collected, coded and controlled information is entered on the SPSS software for data analysis treatment. The registered records constitute a huge database related to numerous key variables and corresponding modalities. Only results regarding selective variables, responding to the concern of this paper, are here analysed. Tables sorted out in a cross tabulation form with the due tests constitute the platform of the data analysis. They are not presented in this paper for commodity raisons, but still available upon request.

In a first tentative to identify the financial profile and behavior of Lebanese, the present work is accordingly limited to a descriptive analysis, based on the achieved tables of the statistical information. The aim of such approach is to assess how much (or how little) Lebanese are informed and care about financial matters with regards to their socio economic background and history. That's why the financial literacy status of the Lebanese is assessed with regards to regional, gender, age group, educational and professional profiles.

\section{Results and Discussion}

The state of the financial information the Lebanese acquire and maintain is for great importance in analyzing their behavior, for it constitutes a main factor expanding or limiting their horizon when doing their life, job or business. The assessment of the financial knowledge authorizes to apprehend the impact of the financial literacy framework on the individual behavior and performance when carrying out regular operations or making more complicated and sophisticated financial decisions. The main findings of this research may be summarized as follow for the specific case of Lebanon.

\section{Financial literacy background}

The statistical analysis shows that whatever the region, gender, age, education and professional profile or social engagement is, Lebanese are satisfied by their level of financial, economic, fiscal, business and labor law knowledge. Nevertheless, males seem notably more satisfied than females from their financial knowledge. Moreover, persons having curricula in business and law express a clearer easiness than unspecialized individuals with business and labor laws, as well with tax procedures and regulations. A sharp divergence exists between poorly 
informed and experts in these domains. However, Lebanese seems well doing with banking operations, whatever their region or age. Still some favor to males who are more familiar with the banking domain.

Lebanese are commonly not interested by financial markets operations and products. Females are moderately concerned by such domain unlike males who are normally more attracted by risky investment. Youths are not sufficiently informed. Familiarity with such kind of information is reachable with age. Still, retired persons have distance with this domain.

It appears that general financial background and economic knowledge are mostly enhanced with the level of education. Graduates from business, economics and law fields of education may be remarkably distinguished by the higher level of knowledge that they receive. No distinction can be made in this regards between the other fields of education and between the types of educational institutions.

The satisfaction about business and labor laws' knowledge grows with level of education for they are acquired at the university, notably in the law field, and enhanced by experience. Illiterate persons seem not endowed with laws' knowledge.

Illiterates and VTE graduates seem to be more comfortable with tax procedures and regulations than university graduates for they have had the opportunity to practice it earlier. Taxation procedures and regulations seems to be better dispensed in law discipline than other fields of education.

Meanwhile a satisfactory level of banking information is not conditioned by the level of education, for everybody generally knows regular banking operations. A high level of banking information is likely obtained progressively with education level. VTE's graduates are well satisfied generally from their banking knowledge. The majority of illiterates declared satisfactory, poor or failing knowledge in banking accounts and operations. A little part of the illiterates expressed good satisfaction because they have had the occasion to deal early with banking operations for the needs of their own business launched just after a training period in an artisanal profession undertaken as a substitute way to education for knowledge acquisition.

It seems that advanced financial knowledge is not generated by the education system but enhanced by personal effort engaged by a little number of individuals searching sophisticated financial products to place exceeding funds or to enlarge portfolio to assure diversity and security or high rewards even in risky investments.

Professions or businesses, generally generating high daily liquidity flows, are more familiar with banking operations and accounts. Lawyers, finance and real estate professionals, accountants and administrative followed by the engineers are the most satisfied by their financial, economic, business and labor law knowledge for their professions are closed to these domains.

Self-employed individuals followed by apprentices and students having job seem to be the most in touch with economic, usual financial matters and juridical aspects.

Business and labor laws knowledge are the mostly apprehended by lawyers, followed by accountants, administrative and information technology professionals, for they are in close and daily contact with conflict issues in performing their jobs.

Whatever is their professional occupation, Lebanese express at some extent similarly fair satisfaction regarding their knowledge in taxation. However, lawyers are likely the most loaded with fiscal information for they are in daily contact with the fiscal jurisdiction to resolve conflict situations, for they take in charge fiscal claims and fiscal operations as representative of business companies and individuals.

Lawyers, finance and real estate officers, accountant and administrative are the mostly endowed with banking knowledge for they manage others' accounts. The role they play as consultants and advisers for their clients or employers, require to acquire punctual banking information. Meanwhile, self-employed, employees and apprentices seem well informed about banking accounts and operations. Students and home wives seem the less endowed with banking information.

Only lawyers, finance and real estate developers are confident for the advanced financial knowledge they deserve, unlike other professions who are not very familiar with financial products and markets. The requested additional time and effort the specific character of these markets requires in terms of daily if not hourly awareness to price fluctuations, and scrupulous attention to the up-to-the-minute information prevailing on markets regarding financial products' ups and downs, render too difficult to those having other occupations not expressing personal pleasant interest to financial issues to pursue the latest information allowing them to realize profit and to avoid imminent fluctuations risk. Selves employed exhibit notable interest to financial products and markets for they see them as potential placements for the generated funds not reused in their businesses. Other professional occupations show moderate awareness for financial markets and products because of the budget and time constraints they face.

\section{Financial information path through}

The financial information may be built up progressively, at home, school, university or by experience. The results of the statistical study show that Lebanese in all regions face the same educational and professional conditions in gathering financial knowledge. It seems that parents and colleagues form the best way to acquire financial information. Home and work place offer better circumstances than educational system to get financial information. Educational system constitutes the poorest environment in which individuals may acquire financial information. Vocational and technical education (VTE) system appears offering the meager learning conditions for financial literacy acquirement. General and vocational educational systems provide unpractical culture for they are limited to basic knowledge non serving for life doing. It appears that individuals should wait to the secondary and university level to discover some of the financial knowledge they build up all along their life. Males and females accumulate the most of their financial skills outside educational system. Nonetheless, males seem to acquire their financial skills at work more than females, and females obtain their financial knowledge at home more than males.

However, younger generations declare having received the major part of their financial knowledge in the education system, notably in the general educational system. The older generations acquired the most of their financial skills in doing life and not in the academic system. Younger generations received less financial information in contact with parents than the older generations have done. Singles seem to receive a remarkable part of their financial education at the academic level.

If the results are shown by level of education, it appears that illiterates, school or university graduates, all believe that they build up 
their financial knowledge mainly at home or at work. The university graduates and doctorates allow higher grade for the university and school in building their financial capacity, VTE graduates believe in the VTE system, and the secondary students give favor to the secondary education, for they experienced each only its own education system.

If the field of education is taken into consideration, it seems that lawyers, business graduates and economists give some importance to the university education to enhance financial literacy, for they received many fundamental courses related to accounting, finance, law, taxation.

With light put on the nature of the profession, financial intermediaries and real estate developers see in the work place the major startup period for accessing useful financial information. For accountants, administrative and lawyers, the university is the main place for recovering financial information, because of the large number of specialized courses directly related to their field of work. Professionals in other sectors make the household responsible for the most of their financial knowledge, where the major part of financial information they acquired is transferred from altruist parents. In such sectors, parents aware to convey financial culture to their child, and try to make their business or job an experience platform for their kids.

With regards to the professional situation, self-employed and retired persons register the work field as the startup place where they accumulated the essential of financial knowledge. Students notice that the university is mainly the startup place and home wife and trainees notice the household the main startup place.

\section{Financial literacy awareness}

When asked about the better place the financial information should be provided, Lebanese from whatever the region, the gender, the marital status, or the social activities favor the home to be the best place where individuals should build up their financial education. They allow a little hope on the academic system to perform their financial knowledge, and intend receive the major part of their financial education early when they still at home, in order to benefit from the contact and advice of parents.

For Lebanese, financial education is apprehended as a culture and a mode of life not learned like any other kind of information at the academic system or acquired later at work. Financial information should be raised early from youngness at home and is considered as nurture financial skills forging the character before accessing real life. The earlier individuals will be accustomed to financial issues, the larger will be the potentials of success in their business and professional life.

Females slightly more than males, and older persons more than younger are aware to the importance of captivating financial skills the earliest possible at home.

Illiterates are the most aware to the necessity of starting early at home the financial education and see in the VTE a potential way to apprehend financial skills. University graduates or doctorate holders believe in the general educational system, and not in the VTE system nor the work place, to be the second best choice after household to acquire financial skills.

Graduates from all fields of education look to the household to be the best place to start financial education, and put the VTE at the last place for this matter.
Professionals in all economic activities prefer largely starting financial learning as soon as possible at home to consolidate financial background before embracing the field work difficulties generated by financial issues. Individuals should be familiarized with financial basics at young age and have a financial culture and character in order to succeed their professional and business life. Some believe that the startup place, if not the home, should be the intermediate or secondary level of general education. A negligible number believes in the VTE system to start financial education. A slight part of individuals only considers that one should wait to university to start financial studies. Those are mainly affiliated to law discipline, and acknowledge well that one should be ready to understand laws and complicated techniques related to financial issues, for they have had the opportunity to remark that financial education should follow other preparatory and supportive courses enhancing the aptitude to understand such a diversified and technically complicated domain.

Individuals in all professional situations presume that home is largely the best place to start financial education, followed by the intermediate and secondary levels of the general education system.

\section{Requested information for life issues}

Whatever the region, age, gender, marital status, social activity or educational profile is, Lebanese express remarkable disinterest for their needs of financial information, notably related to fiscal and insurance issues. Their ignorance of rules and regulation also let thoughts consider a total cut with any matter having relationship with state or security.

Only financial matters related to personal and private concerns retain the attention of Lebanese, whatever their personal profile is. Individuals are mainly worried by their portfolio choices and need information regarding loans, deposits and financial products.

Males express higher attraction and curiosity than females to collect general financial information and related to loan, deposit and financial products.

Illiterates express a relative higher need for fiscal and banking information, graduates in agriculture declare clear needs for banking information as for rules and regulations. Professionals are less ignorant than graduates for their financial information needs, for their experience allowed to define which kind of information is lack and should be make-up. Agricultures look to increase their knowledge regarding deposits and loans, for the particular interest they have to grow their farms and businesses. Constructors and industrials need much more information about financial products as they search alternative placements for the funds they generate from projects. Finance intermediates and real estate developers look to accumulate information regarding rules and regulations, something they need particularly to respect in developing their projects and to deal with their main stakeholder, the state.

Self-employed, employees, and retired require information regarding financial products to place their economies in rewarding and less risky investments. Unemployed look for information on deposits and loans for the need they have to manage their savings and expenses all along the unemployment period. Apprentice and employed student have some declared curiosity to know about banking issues. 


\section{Need for financial advice}

Lebanese from whatever the region they originate, whatever their gender, age class, marital status or engagement in social activities, and whatever their level and field of education or their professional situation, still count at large scale on parents and friends to receive advice regarding financial matters, and at lower but noticeable scale to their bank officers when searching clearer information regarding their financial choices.

Lebanese solicit social media providers more than books, journals or university courses in case of financial information needs for they are easy to access.

While females count more than males on parents and friends and on internet to access needed financial information, males solicit more than females bank officers and advisers. Active persons ask so more than others for financial advice.

An inverse relationship exists between the level of education and the needs for parents and friends, in favor of the financial advisors support. University graduates and doctorate holders count less than school graduates and illiterates on the parents and friends' advice and more and more on banking officers for financial advice. Business and economics graduates countless on parents and friends in case of financial advice need.

Lawyers, industrials, financials and real estate developers counts remarkably on financial magazines and books in searching financial information. Individuals working in communication, real estate, accounting and administration, arts, informatics and students use internet search engines to find financial information.

\section{Purpose of the financial information need}

Lebanese, whatever their region, age, familial status, level and field of education, express commonly similar needs for financial information. Information enlightening saving management is the major need of Lebanese, followed by the intent of avoiding cheating and dishonesty. Females and males express similar concerns for financial information. However, females express relatively lower interest for financial information and seek it mainly to enhance their financial education level.

Active persons are less concerned than teenagers and retired persons by enhancing their general knowledge in finance, for they ask for practical use of financial information. Illiterates express the highest level of disinterest for financial information, and when some interest for is exhibited, it concerns saving management. The level and field of education seem to have no particular effect on the type of the needed financial information.

Individuals from all economic activities search financial information to improve saving management. Lawyers and individual working in media are also mainly interested by financial information to anticipate financial crisis and to enhance their financial education background. Apprentices are looking for financial information equally to better their financial background, improve their performance and increase their potentials for financial assets accumulation.

\section{General education and career success}

Lebanese are largely satisfied from their professional and business life. Only a little part of them has poor satisfaction or a failing career. However, while males exhibit a higher level of satisfaction than females they express also higher level of failure in their career. Females still constitute the major part of those not having yet experience.

Illiterates registered comprehensive success in their career. Illiteracy seems not leading to failure but it constitutes a boundary for any outstanding success. The increased level of education enhances the potential of success. Doctorates registered higher share of outstanding success and no one case of career failure. The VTE system opens more comprehensive success opportunities than university system and prevents from career failure. However, VTE system allows successful, not outstanding career. University system allows higher outstanding career achievement than VTEs and slight cases of breakdown. Graduates in medicine, pharmacology, art and engineering fields registered outstanding career success. Graduates from agriculture, education, tourism, law, business and economics achieve successful careers. The private education system allows higher opportunities for outstanding success than public education sector which captured the largest share of successful careers.

Artisans and agricultures exhibit a dual case. While some of them achieve outstanding careers, and no one case of failure noticed, a noticeable share of poor success subsists. Engineers, medicals, Lawyers, financial officers and real estate developers registered the higher shares of outstanding career success. Traders, industrials, construction developers, transporters, communication and media, lawyers, finance and real estate developers, accountants and administrative, artists, artisans, teachers, army and police officers announce largely a successful career.

\section{Financial education and career success}

The financial literacy profile constitutes a support to the individuals. The high dependency nowadays of all economic fields and professions on financial concerns let the financial knowledge as a prerequisite to successful management of personal, job and business affairs or at least to avoid career problems. No field is actually outside of the financial sphere, and no individual decision is away from financial consequences. Financial literacy enhances capacity and improves good prospect to achieve a successful or outstanding career. Successful opportunities grow with the increasing financial literacy background. A poor or failing financial background leads mainly to fair and poor career, restricts the chances to make outstanding success and reduces occasions to achieve successful career. Consequently, financial literacy is a great plus for achieving career success in complement of technical knowledge in all professional fields. Without a good financial literacy level, opportunities to achieve career success are downward. Be professional and efficient in one domain is not a sufficient condition to achieve career success.

Is the financial literacy a determinant factor of career success for Lebanese? It seems from the statistical results that individuals believing in the direct effect of financial education on career success have an outstanding career. They have had the occasion to experience the capability the financial education allows in doing business and making personal decisions. In fact, the acquired financial education forms the basic platform in performing job for it enhances potentials and opens horizons to embrace ideas, financial tools and techniques of nowadays. However, while individuals declaring outstanding careers form the major part of those believing in the direct effect of financial education on career success, those experiencing successful life believe in high effect of financial education on career success. Those declaring fair success believe in lower insights of the financial education on career success, and those having poor success in their careers find no 
relationship between financial education and career success or they don't know if such a relationship exists.

Moreover, individuals having outstanding careers put the financial education level at the top of scale of factors affecting career success, followed by parents' financial experience, personal financial experience and financial experts' advice. Successful individuals put the financial education effect on the second stage of the scale after the personal financial experience. Fairly succeeding individuals attribute it mainly to the experts' advice and the parents' financial experience. Individuals experiencing poor success see in the parents' financial experience a major factor affecting career success, even it is too limited for them.

The major part of those not believing in their financial success belongs to successful and fairly satisfied categories from their work and personal life.

Nevertheless, it seems that the context where financial knowledge begins (at home, school, university or work) does not affect the ability of individuals to achieve outstanding and successful experience. The startup period of financial information acquisition have no particular effect on career success. No matter the startup period is, better self in financial concerns enhance opportunities to succeed in work and personal life. Still, Lebanese, whatever is their level of career success, believe that parents and friends form the main source of advice, followed by the banking officers' advice.

In the other side, individuals achieving outstanding and successful careers revealed that they didn't face any downturn and those they faced it admit largely that financial education level is not behind downturns. Only failing persons attribute their downturns mainly to financial education level.

Moreover, financial management difficulties seems not being the main cause of career failure. Such difficulties face mainly individuals achieving successful and outstanding careers for they have had the opportunity to experience them in developing their affairs or doing their job. In addition, individuals achieving outstanding career attribute the main source of financial management difficulties to not asking financial experts or to their risky behavior in finance. They classified the limited experience in finance at the top of career failure causes, followed long after by the weakness of financial education, and by the arbitral made choices. Successful persons attributed the financial difficulties they faced mainly to out of control major forces, followed by not soliciting the advice of financial experts and by their weak financial education level.

\section{Familiarity with financial institution and career success}

Familiarity with financial institutions comes when individuals feel well suited by a sufficient baggage of knowledge related to the financial regulations, practices and products, letting them unreservedly multiply frequentation to the financial institutions. Progressively, they build up a certain level of confidence in their capacity to perform properly financial operations and transactions, allowing them to deal easily with financial institutions, expecting catch opportunities and facilities. Gradually, the frequency of dealing with banks allows acquaintance, skills and easiness in performing financial transactions. In contrary, the ignorance of the banking services make individuals fear to approach banks, which in return limits their accessibility to convenient financial information and push them out of the financial sphere. Consequently, a lack of confidence in banks and their advice will be established, rendering occasional the contact with them or limit it to the ultimate need.
It appears that contacts with banks and financial markets improve potentials for personal success. Successful persons and those achieving outstanding careers have daily deals with banks and at lower extent with financial markets. Individuals having a little access to banks' services and to financial markets registered less successful careers than those are in close contact. In addition, failing and poorly satisfied person from their career don't have any noticeable contact with banks.

However, Lebanese transactions in stock and exchange markets are too limited generally, if not existing. Financial market fluctuations are the major cause of fear, limiting transactions in stock and exchange rate markets. In addition, financial markets require less contact than banks to assure similar level of individual performance. Their long term framework doesn't request frequent contacts to assure tracking and follow up of the financial products fluctuations. Finally, it's worth to note that only individuals not fearing deal with stock and exchange markets have daily or slightly less frequent contacts with banks.

\section{Personal finance management of life issues and career success}

The way people manage their budgets is for great importance to assure constantly life issues without any accidental calamity. It constitutes the platform for personal and career success. The results of the statistical study show that half of Lebanese people don't do any plan at short term for spending large amount of money and doesn't know how to finance such large expenditures related to vital step of their life. Housing concerns form the top worry of Lebanese among other valuable spending followed by the education, transport and health considerations.

It appears that Lebanese count first on their proper economy to achieve life-size issues. They are also able to do much sacrifices and increased effort before soliciting banks. They use their economy mainly to finance housing, education and at lower extent to buy a car or to cover unexpected health needs. They count on their personal effort and on parents and friends' support mainly to finance housing or to buy a car and to face education payments. They solicit banks mainly for house and car loans. They buy insurance policy mainly to cover health and educational issues, and to assure kids future from unpredicted accidents. They accumulate also precious assets to finance housing or educational expenditures and at lower extent to face health problems.

Lebanese admit well that planning expenditures is a condition to success. Individuals achieving successful or outstanding career don't spend arbitrary and don't count on parents help. Successful individuals spend money according to a spending plan or to a budget constraint. In addition, individuals achieving successful careers are the most respecting their engagements. Individuals failing their careers are the most facing difficulties in respecting engagements.

It appears also that capability to fulfill regular engagements is influenced by the mode of managing funds and spending. Individuals managing their expenditures according to a plan or to income, form the major part of individuals fulfilling completely or with some delay their engagements. Individuals spending arbitrarily or counting on the parents supports have no banking accounts and have less chance to meet regularly engagements' due dates. Individuals not having any banking accounts are mainly from those trying justly to match spending to income or from those spending by what's given by parents. Major part of individuals notifying no one finance overdrawn the last time, are from those managing their expenditures according to income 
Page 7 of 8

or to a plan. Individuals spending according to plan or to income are mainly from those never facing finance overdrawn last time.

\section{Advanced financial literacy, risk perception and awareness}

Lebanese, whatever is their region, age class, gender, and social activity ignore the risky nature of the financial products and the fundamental characteristics of the financial placements. However, males seem more informed and aware than females to the risk feature characterizing the different financial products.

For Lebanese, risk is mainly growing with the placement lengthy. Contrarily to what is conventionally known, for them long term financial products, like stocks and at lower extent bonds, are riskier than short term placements. The causes are related to the political and economic instability, the insecurity, the small size of the stock market, the asymmetric information and discrimination aspects restricting the financial market framework to a limited band of politicians and influents, the ambiguousness and doubts surrounding past operations, the market rules and quotation misinformation.

Short and middle term placements, like exchange rate operations, banking accounts and insurance, seem to be the most secure placements for Lebanese. Stability of the exchange rate policy, confidence in the banking system and in insurance companies supported generally by external partnerships are the main reasons.

For Lebanese, direct investments are enticed by a relatively higher risk level. Prevailing uncertainty ambiance, ineffectiveness of the judiciary system, public administrations situation shaped by inefficiency and corruption are the essential raisons.

The level and field of education seem not having any remarkable effect on the individual character and risk features knowledge. Nonetheless, illiterates ignore totally the risk character of the various financial products. More than a half of them declare failing to express their opinion regarding the riskiest type of placement, the second half allows exclusively higher risk degree to stocks and at lower extent to bonds.

Among the professions, the financial experts, real estate developers and at lower extent lawyers are the best informed regarding the risk status of financial products. They allow also no risk to saving accounts and highest risk degree to stocks and at lower extent to direct investment, followed by bonds and exchange rates, the latest being defined by governmental and monetary stable policy. The professional occupation status seems to have no noticeable effect of the level of knowledge regarding risk features of the divers financial products.

\section{Finance overdrawn frequency and management}

The finance overdrawn may result from an occasional mistake, laxness in punctuality and unsuitable accounts control, or from external major forces. Laxness may be due purely to the character of the individual or to the poor financial literacy he deserves, letting him not giving the interest it dues to the financial aspects of his life. The nonchalant behavior of the individual regarding financial terms makes him largely disposed to overdrawn risks.

Whatever is the raison, approach the individuals undertake in trying to overcome the financial difficulties is an important issue. The way the financial difficulty is managed could allow power to overpass it without major consequences. The statistical results show that individuals having found solution to financial overdrawn, in whatever is the way, are not marked by, and consider they have never faced a financial difficulty. What's important is to find the solution, whatever is.

Many alternatives exist to overcome overdrawn, starting by the withdrawal from savings and credit card, passing by stop spending, soliciting banking facilities or borrowing money from other sources, ending by selling assets.

It appears that, whatever is the frequency of the financial difficulties, individuals turn first to their previous economies then stop spending and extend work time. Individuals facing financial difficulties once a year prefer solicit lenders to extend work time in order to make up deficient amounts. And, whatever is the frequency of a finance overdrawn it seems that relatively a non-negligible share of individuals don't know how much savings may suffice in case of income cut. And, a significant part of them has never experienced an overdrawn.

So surprising, a significant share of Lebanese still haven't any banking account and mostly do not reveal having experienced substantial financial overdrawn. A considerable share of individuals the economies suffices shortly in case of drastic income cut, have no banking account, contrary to those having economies sufficient for long term from whom only a slight share haven't banking account. Also, a substantial share of individuals not capable to expect the covering duration of their saving has no banking account. Individuals having no banking account stop spending, use their economies or extend their work time to avoid financial deficiencies.

It appears also that the share of individuals never experienced an overdrawn increase with the time period the savings suffice in case of income cut. The longer is the period of time the savings are expected to cover life expenses in case of income cut, the highest is the possibility to ovoid a financial overdrawn.

\section{Conclusion}

Financial literacy still presents great interest for many researchers. The framework of the related studies varies to cover the large length of concerns in touch with this topic. The concept of financial literacy is not defined and reflected by only one measurable indicator. It forms a framework of study with many facets and a wide range of related issues. It's too difficult to fix boundary for such a concept, for it surrounds with time a growing area of interests and form a broad and hard to define character. To constitute an idea about the financial literacy strength and its impact on individuals' behaviors and success, a composed multi criteria index should be developed.

The aim of this paper is to shed light on some important aspects of the financial literacy, using descriptive analysis approach as a first tentative to apprehend its multifaceted nature. For this purpose, a survey is conducted for a small open economy like Lebanese one. A comprehensive and representative sample is randomly selected for this concern. The financial literacy status is assessed through different criteria and with regards to regional, gender, age group, educational and professional profiles.

It appears that whatever is their region, age, gender, marital status, social activity, educational profile and professional situation, Lebanese believe they are endowed by a satisfied level of knowledge in finance, economy, taxation, business and labor law. They seem well doing with banking operations but not interested by financial markets operations and products. They accord attention to financial matters related to personal and private concerns, like saving management and cheating 
Page 8 of 8

avoidance, and express remarkable disinterest for their needs of financial information, notably related to regulations, fiscal and insurance issues. Their transactions in stock and exchange markets are too limited generally, if not existing. They ignore the risky nature of the financial products and the fundamental characteristics of the financial placements. For them, direct investments and long term financial products, like stocks and at lower extent bonds, are riskier than short term placements, like exchange rate operations and banking accounts.

While for Lebanese, business and labor laws knowledge grows with level of education, banking information is not conditioned by the level of education. However, it seems that home and work place offer better circumstances than educational system to get financial information. Individuals still count at large scale on parents and friends to receive advice regarding financial matters, and at lower but noticeable scale on their bank officers when searching clearer information regarding their financial choices.

Lebanese are largely satisfied from their professional and business life. And, for them, financial management difficulties seems not being the main cause of career failure. However, while individuals declaring outstanding careers have daily deals with banks and at lower extent with financial markets, and form the major part of those believing in the direct effect of financial education on career success, those declaring fair success have a little access to banks' services and believe in lower insights of the financial education on career success.

The half of individuals doesn't do any plan for spending large amount of money. Housing concerns form the top worry of Lebanese, followed by the education, transport and health considerations. It appears that they count first on their proper economy to achieve lifesize issues. They solicit banks mainly for house and car loans. Yet, a significant share still haven't any banking account and mostly do not reveal having experienced substantial financial overdrawn. A nonnegligible share of individuals doesn't know how much savings may suffice in case of income cut. However, individuals managing their expenditures according to a plan or to income, form the major part of individuals fulfilling completely or with little delay their engagements. Individuals spending arbitrarily or counting on the parents supports have no banking accounts and have less chance to meet regularly due dates.

Now, that the financial character and behavior of Lebanese have been defined in a descriptive analysis, another study, based on more sophisticated tools, is planned. In a factorial modeling approach, we project to define the factors affecting the financial literacy skills and capability and to develop relationships expressing the place that financial literacy occupies in the career success determinants matrix.

\section{References}

1. Roy Morgan Research (2003) ANZ survey of adult financial literacy in Australia. Final report prepared for ANZ Banking Group.

2. Ibrahim ME, Alqaydi FR (2013) Financial literacy, personal attitude, and forms of personal debt among residents of the U.A.E. Int J Econ Financ 5: 126-138.

3. Huston SJ (2010) Measuring financial literacy. J Consum Affairs 44: 296-316.
4. Remund DL (2010) Financial literacy explicated: The case for a clear definition in an increasingly complex economy. J Consum Affairs 44: 276-295.

5. Australian Securities and Investments Commission (ASIC) (2011) National financial literacy strategy.

6. McKay S (2011) Comprendre la capacité financière au Canada. Analyse des résultats de l'Enquête canadienne sur les capacités financières, document de recherche prepare pour le Groupe de travail sur la littératie financière.

7. Bay C, Catasus B, Johed G (2014) Situating financial literacy. Crit Perspect Account 25: 36-45.

8. Aprea C, Wuttke E, Breuer K, Koh NK, Davies P, et al., (2016) International handbook of financial literacy, Springer.

9. Lusardi A, Mitchell OS, Curto V (2010) Financial literacy among the young. J Consum Affairs 44: 358-380.

10. Cameron M, Calderwood R, Cox A, Lim S, Yamaoka M (2013) Factors associated with financial literacy among high school students, University of Waikato, New Zealand.

11. Eniola AA, Entebang H (2017) SME managers and financial literacy. Glob Bus Rev 8: 559-576.

12. Kerkmann B, Lee T, Lown J, Allgood S (2000) Financial management, financial problems and marital satisfaction among recently married university students. Financ Counsel Plann Educ.

13. Chen H, Volpe RP (1998) An Analysis of personal financial literacy among college students. Financ Serv Rev 7: 107-128.

14. Lusardi A, Mitchell OS (2013) The economic importance of financial literacy: theory and evidence. J Econ Lit.

15. Ludlum M, Tilker K, Ritter D, Cowart T, Xu W et al., (2012) Financial literacy and credit cards: A multi campus survey. Int J Bus Soc Sci 3: 25-33.

16. Nidar SR, Bestari S (2012) Personal financial literacy among university students (case study at Padjadjaran University students, Bandung, Indonesia). World J Soc Sci 2: 162-171.

17. Robb CA, Sharpe DL (2009) Effect of personal financial knowledge on college students' credit card behavior. J Financ Counsel Plann 20: 25-43.

18. Porto N, Xiao J (2016) Financial literacy overconfidence and financial advice seeking. J Financ Serv Prof 70: 78-88.

19. Agnew JR, Szykman LR (2005) Asset allocation and information overload: The influence of information display, asset choice, and investor experience. J Behav Financ 6: 57-70.

20. Harrison T (2016) Financial literacy and the limits of financial decisionmaking, Palgrave, Macmillan, Springer Nature, New York.

21. Lusardi A, Mitchell OS (2011) The outlook for financial literacy. In Financial Literacy: Implications for Retirement Security and the Financial Marketplace. Mitchell OS, Lusardi A editors. Oxford, Oxford University Press: 1-15.

22. Lusardi A, Mitchell OS (2011) Financial literacy around the world: an overview. J Pension Econ Financ 10: 497-508.

23. Jappelli $\mathrm{T}$, Padula $\mathrm{M}$ (2011) Investment in financial literacy and saving decisions, Center for Financial Studies (CFS) Working Paper.

24. Calvet LE, Campbell JY, Sodini P (2007) Down or out: assessing the welfare costs of household investment mistakes. J Polit Econ 115: 707-747.

25. O'Neill B, Sorhaindo B, Prawitz A, Kim J, Garman T (2006) Financial distress: definition, effects and measurement. Consum Interests Annu. 